\title{
An Experiment in Library Instruction For Business Students
}

$\mathrm{T}$ HERE IS SMALL doubt in the minds of many educators that students are entering the universities today inadequately prepared in the skills demanded by so-called higher education. This is an immediate dilemma. There is no need to explore students' past histories to discover reasons for this situation. The fact is present and must be solved in the present and very near future for and by these students.

One of the skills needed by the university student is a working knowledge of the research library and its tools. Too few students seem to have come from high schools with libraries of any size, or if they have, they show little evidence of having learned basic library procedures. Most college and university libraries therefore have some plan of instruction in necessary techniques for entering students. At the University of North Carolina during the orientation periods at the beginning of the semester, freshmen are given a series of two lectures plus practical assignments covering the content of these classes.

While this instruction is all to the good, it has been my experience as the librarian of a special collection that by the time the student enters the School of Business Administration as a junior, he has forgotten independent library procedures either because of total disuse or because of the somewhat doubtful blessings of the efficient reserve book system. The ultimate shock in this area was the case of the graduate student who came in

Miss Georgi is Business Administration Librarian, University of North Carolina. despairingly seeking aid in writing the first term paper of her entire academic career for a seminar assignment!

An accumulation of such experiences with confused, befuddled, and sometimes rather desperate students led the writer to devise some methods to impart essential knowledge of library tools and use. Thanks to the professor teaching the graduate course in bibliography and research methods for the Master of Business Administration program, I was given both my start and my inspiration. He invited me to give a series of two or three lectures on the use of the business library and its materials to his class of graduate students. Not knowing exactly what was needed or wanted, some mimeographed pages of explanations and bibliographies, which have been since revised, were prepared and used as a basis for subsequent developments of teaching materials.

The first page of data prepared was concerned with the most elementary information: the card catalog, the index services, the Dewey classification schedules most used by business and economics students, a brief list of books on business information and reference tools, and mention of other collections in the library having relevant materials, the Documents Department and the North Carolina Room. This has proved to be a good outline for a basic lecture assuming that the student knows almost nothing about a research library. This, together with a brief tour to the various parts of the Business Administration and Economics Library and a copy of the sixteen page University of North Carolina gen- 
eral Library Handbook describing the entire library system, proves to be an effective, if routine, introductory talk.

The second page, entitled "General Source Tools for Business and Economics Reference Data," is divided into four sections: Directories and Registers; Dictionaries and Encyclopedias; Handbooks, Almanacs, and Guides; Magazines, Newspapers, and Publications. This goes on to describe the essential tools which should be known to business and economics students, such as Thomas' Register of American Manufacturers, the Poor's Register of Directors and Executives, the Economic Almanac, etc. This forms the basis of the second lecture.

These two lectures are offered to students entering the School of Business Administration and who are enrolled in the basic courses. They are followed by a twenty-five question true-false assignment involving actual examination of the various tools and techniques described and discussed. This paper can be graded and corrected quickly and sent to the professor of the students involved.

There is nothing compulsory about this program. Professors are invited, on an optional basis, to make arrangements to bring their classes, during regular class hours, to the library for these lectures, These two lectures are given to students in the basic courses required of business administration majors. For advanced students in the special fields, additional materials have been prepared for discussions aiming at their individual needs.

For this purpose a third section of mimeographed pages is available, "Suggested Reference Tools in Specific Areas of Economics and Business Administration." In this, brief bibliographies of recommended reference tools are given in fourteen fields: accounting, advertising and sales, banking and finance, business administration and organization, foreign trade, industrial production, insurance, investments, labor relations, marketing, personnel and industrial relations, real estate, taxation, and transportation. In addition, two other pages have been prepared, "Recommended Government Publications for Economics and Business Research," and "Finance-Investments: Specific Company Data; Advisory and Forecasting Services."

From time to time, students and faculty are interested in knowing what titles are available in inexpensive editions. This demand has given rise to still more mimeographed sheets, "Paperbound Books in Business and Economics: A Bibliography." This is revised annually and the latest edition includes fifteen categories: accounting, advertising-marketing, business, economics, insurance, labor, law, mathematics-statistics, moneybanking-corporation finance, personnel, philosophy, real estate, reference, shorthand and typing, transportation. To date, this has proved to be more popular in farther fields. About two hundred copies have been sent out to public, college and university, high school, government, and special company libraries.

All in all, over fifty lectures have been given to a total of over six hundred students during the past year, all of whom were brought to the Business Administration and Economics Library during regular class hours at the option of their instructors. At present, this type of instruction is not a regular part of the business curriculum. The results? No effort has yet been made to assess them scientifically. The general impression is that students get to know where the Business Administration Library is, that they realize certain information can be located by the use of certain tools, and, above all, they know that if they forget just what does what, there is someone there trained to help them. We are satisfied that this is one small step in the right direction. 